\title{
Theology and the (post)Apartheid condition: A response
}

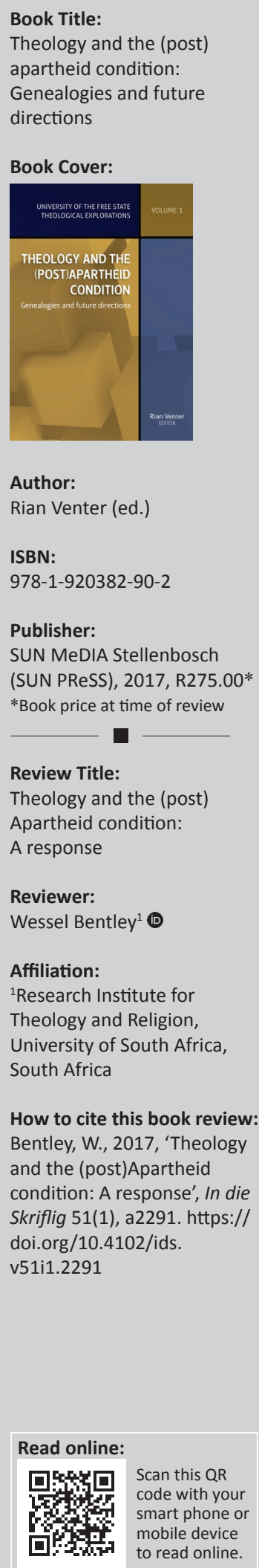

How to cite this book review: Bentley, W., 2017, 'Theology and the (post)Apartheid condition: A response', In die Skriflig 51(1), a2291. https:// doi.org/10.4102/ids. v51i1.2291

In this edited volume, contributors from the disciplines of Old Testament, New Testament, Systematic Theology, Practical Theology and Missiology engage in developing a wide-ranging response to the challenges faced in post-Apartheid South Africa. The critical question posed in this publication is: Seeing that theology is largely framed from a contextual base, where has the theological discourse moved to in this post-Apartheid era of South African history?

The question posed is indeed of merit, as many South African theological research outputs seem to have got caught up in the sticky place of simply reflecting backwards on the legacy of Apartheid, without moving the conversation significantly forward. So, what does a contemporary postApartheid South African theology look like? Of course this book cannot give an all-encompassing response to this question, but dares to make the first small steps in the conversation.

Written mainly for an academic theological audience, Rian Venter introduces the conversation by mapping the post-Apartheid condition. He describes the current South African theological discourse in the context of theological education; how various theological disciplines have engaged society on the meaning of the post-Apartheid South African context; and how these disciplines have sought to be instrumental in social transformation. This is a helpful introduction, as it provides a solid foundation from where the other contributors could make their case. In the introductory section of this book, the contribution by Resane is of particular value, as he plots the shifting theological horizons during the past two decades.

From the perspective of Old Testament studies, Schmidt and Snyman ask questions about wisdom and the meaning of prophetic voices, particularly as understood by (mainly reformed) theologians during the South African transition years. The New Testament section offers only one voice, but nonetheless a valuable one, namely of Tolmie who asks whether anything has changed in the last 50 years in South African Pauline studies. He concludes that some significant changes can be noted, sparked by socio-political and historical transitions.

Urbaniak and Venter contribute from the discipline of Systematic Theology. Urbaniak compares the prophetic voices of Koopman and Maluleke, while Venter engages the reader on the changing understanding of the doctrine of God in the post-South African context. Laubscher and Wessels, Pali, and Schoeman and Van den Berg then contribute three chapters from the discipline of Practical Theology, weighing in on how we witness the changing understanding of Christianity's prophetic witness, leadership and interdisciplinary practices. Van der Watt concludes the conversation from Missiology, asking what mission looks like in post-Apartheid South Africa.

If the reader is interested in a holistic approach to the theological discourse and practice in the South African context, then this book would be a good starting point.

For practical reasons one can understand that this book focuses mainly on the question of contextual theology from the reformed perspective, as contributors or contributions are placed in this theological tradition. Even a Catholic theologian like Urbaniak investigates reformed theologians. This should be counted as a point in favour of this book for two reasons. Firstly, it creates the scope to investigate the research question from Christian traditions outside the reformed tradition. This can be an ongoing work and facilitate conversations across the boundaries of ecclesiastical confessions. Secondly, it creates for the critic of the reformed tradition, a response which says that although Apartheid is an act of generalisation, seen as historically associated with Apartheid, the reformed tradition is (and has been) actively engaging with its own identity in post-Apartheid South Africa.

Copyright: @ 2017. The Authors. Licensee: AOSIS. This work is licensed under the Creative Commons Attribution License. 
In this publication, space is offered for different cultural voices and generations, but not - and this is my main critique clearly for the voice of women. It would have been of great value to hear women's voices in this regard; how have women experienced the changes in theological discourse in the last 20-odd years? Or has there been no change for women?

Overall, I enjoyed reading this book. It has put into words what we have been quietly witnessing in theological discourse in our beautiful country. Venter and the contributors need to be thanked for taking a deliberate step in outlining the spaces and perspectives occupied by the different theological disciplines in the reformed tradition. I look forward to seeing how this work is expanded, so as to become a bridgebuilding conversation between Christian traditions in South Africa. 